This is a self-archived version of an original article. This version may differ from the original in pagination and typographic details.

Author(s): Shah, Syed Adil; Bhutto, Maqsood Hussain; Azhar, Sarwar M.

Title: Integrative review of Islamic marketing

Year: 2022

Version: Accepted version (Final draft)

Copyright: @ Emerald, 2021

Rights: $C C B Y-N C 4.0$

Rights url: https://creativecommons.org/licenses/by-nc/4.0/

Please cite the original version:

Shah, S. A., Bhutto, M. H., \& Azhar, S. M. (2022). Integrative review of Islamic marketing. Journal of Islamic Marketing, 13(6), 1264-1287. https://doi.org/10.1108/JIMA-07-2020-0216 


\title{
Integrative review of Islamic marketing
}

\author{
Syed Adil Shah \\ Department of Business Administration, Sukkur IBA University, Sukkur, Pakistan \\ Maqsood Hussain Bhutto \\ School of Business and Economics, Jyväskylä University, Jyvaskyla, Finland, and \\ Sarwar M. Azhar \\ Department of Business Administration, Sukkur IBA University, Sukkur, Pakistan
}

\begin{abstract}
Purpose - The purpose of this study is to integrate and synthesize the Islamic marketing literature, understand the phenomenon and related concepts and provide suggestions for future research.
\end{abstract}

Design/Methodology/approach - The study uses an integrative review method that emphasizes summarizing and synthesizing the previous literature related to a phenomenon.

Findings - The findings indicate the emergence of five major themes, namely, Islamic marketing and its perspectives, activities in Islamic marketing, opportunities, controversies and challenges in Islamic marketing, Islamic principles and determinants of consumers' behavior and awareness toward Islamic products. Each of the major themes consists of subthemes discussed in detail in the results and discussion sections.

Research limitations/implications - Like other studies, this integrative literature review has some limitations. These include the methodology undertaken, the lack of explanation of interrelationship among themes and lack of Islamic theory-based review. These limitations lead to future research directions.

Practical implications - Marketing managers need a thorough understanding of the Islamic standards and need to develop strategies. Further, there are inter-differences among Muslims, which need to be thoroughly understood by managers. Moreover, marketers can effectively use advertising in creating awareness and increasing demand of halal products.

Originality/Value - This study provides an integrative review of the literature and synthesizes the Islamic marketing literature, which has not been done before.

Keywords: Halal market, Islamic marketing, Islamic marketing mix, Muslim consumers, Halal marketing, Integrative review

Paper type: Literature review

\section{Introduction}

Since the past decade, a lot of efforts have been directed toward marketing based on religion targeting specific religious groups. In this regard, Izberk-Bilgin and Nakata (2016) reported that marketers are using religion-based marketing to address the needs of customers. 
Recently, the Muslims' consumer market has gained a lot of attention from marketers, who are actively pursuing Muslims' market as a segment to attract them by addressing their needs emotionally. Regarding the Muslims' market, Izberk-Bilgin and Nakata (2016) reported that progressive companies are already building their customer base by using halal/Islamic marketing to attract Muslims, which is the fastest-growing religious segment. This growing interest in Islamic marketing is because of the large Muslim population, high economic growth of Muslims and a growing demand for halal products.

The Muslim population is currently the second largest in the world and is regarded to be the fastest growing in the world, which is projected to grow at a rate of $1.5 \%$ almost twice than that of $0.7 \%$ for non-Muslims (Johnson and Grim, 2013). The Muslim market is a relatively young consumers' market with an average age of 24 , that needs to be thoroughly studied in terms of problems and consumption patterns (Kadirov, 2020). Furthermore, the halal business is huge in size. According to the World Halal Forum, the global halal business excluding banking sector was estimated to be worth US\$2.3tn in 2010 (Rahim, 2016; The Halal Journal, July and August, 2010). Furthermore, the growth rate of the halal market is considered the highest in the world (Abu-Daabes, 2018; Alserhan, 2010a). With this rapid increase in the halal-based market and consequently halal/Islamic marketing, there has also been a growing interest in the academic field on the subject.

Sandikci (2011) denoted this interest among academics and marketing practitioners with the goal of understanding Muslim consumers and developing strategies to target this most attractive market segment. However, Wilson et al. (2013) indicated that there is a scarcity of theory and practice in the area of Islamic marketing. Furthermore, the extant research has mainly focused on size of markets, demand for halal and Muslims population (Wilson, 2014a, 2014b). In pursuing this line of thought, Ahmad (2018) noted that previous studies have mainly focused on Muslim consumers' markets, Islamic branding, halal (lawful from Shariah perspective) products and services, while ignoring what actually Islamic marketing is. The present study, therefore, is an attempt to organize and synthesize the Islamic marketing literature to develop further understanding of the phenomenon and its related concepts. While doing so, this paper traces the progress of Islamic marketing research and also provides suggestions for future research.

\section{Methodology for Integrative review}

An integrative review is a particular method of reviewing the literature, which focuses on summarizing and synthesizing past literature to provide a thorough understanding of a specific phenomenon (Whittemore and Knafl, 2005; Cooper, 1982), in such a way that new perspectives and framework are generated (Torraco, 2005). An integrative review embodies a number of purposes, including defining concepts, reviewing theories and evidence and analyzing methodological issues (Whittemore and Knafl, 2005; Broome, 1993), and may involve mature or emerging and new topics (Torraco, 2005). In the present study, the area of interest is Islamic/halal marketing as a subject of our enquiry and focuses on developing an understanding of this emerging phenomenon. This next section provides details of the methodology used for the integrative literature review.

\section{Data Collection}

Relevant studies for literature review were searched in electronic databases, including Wiley Online; Taylor and Francis; Emerald Insight; ABI informs; ScienceDirect and Sage. The databases mentioned above were searched by using keywords "Islamic marketing" and "Halal marketing." The number of search results for the initial keywords search across the 
databases are given in Table 1. These studies were then used to generate further reference and literature search using snowballing in literature review (Wohlin, 2014). There was no limitation placed on the period of publication. However, as the review was carried out in early 2019, the reported articles included in the process are until 2018.

Table 1: Results for searched keywords in literature and databases

\begin{tabular}{llllll}
\hline Keywords & Wileyonline & Emerald Insight & Sciencedirect & Tandfonline & Informs \\
\hline & & & & & \\
& & & & & \\
"Islamic marketing" & 28 & 133 & 58 & 25 & 0 \\
"Halal marketing" & 2 & 14 & 9 & 5 & 0 \\
\hline Total & 30 & 147 & 67 & 30 & 0 \\
\hline
\end{tabular}

\section{Articles Selection and inclusion Criteria}

The literature to be selected for this paper was based on various steps. First, to select the articles to be included in the review, the titles and keywords of the retrieved studies were JIMA analyzed. Second, the abstracts of the articles were scanned for keywords "Islamic marketing" or "Halal marketing" to evaluate their relevance for Islamic marketing. Those articles that did not include these phrases were excluded from further review. Subsequently, the abstracts were carefully read to ensure that these were relevant to the topic of interest (Ranjan and Read, 2016) and excluded non-relevant studies (Dangelico and Vocalelli, 2017).

Finally, the full texts were analyzed to ensure that each study contributed to the understanding of the topic and relevant perspectives to delineate themes that will enable us to form the basis of a holistic view of the subject matter. Besides the above criteria, the inclusion of the studies was limited to peer-reviewed journals (Parris and Peachey, 2013) and book chapters. The number of articles that were used to carry out further analysis, matched a similar number of articles used by Parris and Peachey (2013), Soares et al. (2014) and Haman et al. (2015) approach. The articles were considered sufficient for the research paper. Further, using backward referencing, the selected studies were then used to generate further studies carried out in the past to be included in the review (Wohlgezogen et al., 2020).

\section{Data Extraction}

The full-texts of the studies were read carefully, and themes were extracted that have a number of dimensions with relevance to the phenomenon of Islamic marketing. Because of the focus of the study, the data extraction focused on the points that provide an understanding of Islamic/halal marketing concepts that could explicate Islamic marketing in a systematic manner.

\section{Results}

The results section provides various thematic aspects that emerged from the review of the literature process, and an attempt has been made to integrate and synthesize the materials drawn from the selected studies to form a comprehensive view of Islamic Marketing. Table 2 shows the themes that emerged as well as their references from where these themes well located.

Table 2: Thematic aspects emerged from the review and their references 


\begin{tabular}{|c|c|}
\hline Themes & References \\
\hline $\begin{array}{l}\text { What is Islamic/Halal } \\
\text { marketing }\end{array}$ & $\begin{array}{l}\text { Rahim (2016), Wilson (2012, p.6), Wilson and Liu (2010), } \\
\text { Haque (2011), El-Bassiouny et al., (2017), Alserhan (2015), } \\
\text { Ahmad (2018), Hassan et al., (2008), Mutum (2016), Saeed et } \\
\text { al., (2001), Hossain et al., (2018), Izberk-Bilgin and Nakata } \\
\text { (2016), Tournois and Aoun (2012) Temporal (2011), Abu- } \\
\text { Daabes (2018) Shamsudin and Abd Rahman (2014), Kadirov } \\
\text { (2014), Abdullah and Ahmad (2017), Zakariya and Abdul-Talib } \\
\text { (2010), Tournois and Aoun (2012), Fraedrich et al.(2018), } \\
\text { Adnan (2013), Abu-Daabes (2018), Wilson and Grant (2013), } \\
\text { Al-Nashmi and Almamary (2017), Sula and Kartajaya (2006), } \\
\text { and Arham (2010). }\end{array}$ \\
\hline $\begin{array}{l}\text { Macro-marketing } \\
\text { perspective }\end{array}$ & $\begin{array}{l}\text { Abdullah and Ahmad (2010), El-Bassiouny et al. (2017), } \\
\text { Ghazali and Mutum (2016), Kadirov (2014), Alserhan (2010b), } \\
\text { El-Bassiouny (2014), Abu-Daabes (2018), Hussnain (2011), } \\
\text { Ghazali and Mutum (2016), Marinova et al. (2008). }\end{array}$ \\
\hline Islamic marketing mix & $\begin{array}{l}\text { Rahim (2016), Maxim (2009), Arham (2010), Trim (2008; } \\
\text { 2009), Al-Fatih (2009), Ahmed and Rahman (2015), Arham } \\
\text { (2010), Mutum (2016), }\end{array}$ \\
\hline Target and Approach & $\begin{array}{l}\text { Sandikci (2011), Wilson (2012), Ahmad (2018), Wilson (2014), } \\
\text { Abdul-Talib and Abd-Razak (2013), Hashim and Othman } \\
\text { (2011), Rahim (2016) Muhammad et al. (2009), El-Bassiouny } \\
\text { (2015), and Kadirov (2014). }\end{array}$ \\
\hline $\begin{array}{l}\text { Issues and Challenges in } \\
\text { Islamic marketing }\end{array}$ & $\begin{array}{l}\text { Rahim (2016), Izberk-Bilgin and Nakata (2016), Sandicki } \\
\text { (2011), Ahmad (2018), Jafari (2012), Abu-Daabes (2018), } \\
\text { Kadirov (2014), Hussnain (2011), Abdul-Talib and Abd-Razak } \\
(2013, \text { p.189), and Drucker and Maciariello (2004). }\end{array}$ \\
\hline $\begin{array}{l}\text { Controversies in Islamic } \\
\text { marketing }\end{array}$ & Abu-Daabes (2018), and Jafari (2012). \\
\hline Islamic guidelines & $\begin{array}{l}\text { Jafari (2012), Jafari and Suerdem (2012), Rahim (2016), Kamali } \\
\text { (2008), Arham (2010), Alhabshi (1987), Haneef (1997), Mutum } \\
\text { (2016), Rahim (2016, p.274), and Al-Mubarak (2010). }\end{array}$ \\
\hline Halal & $\begin{array}{l}\text { Izberk-Bilgin and Nakata (2016), Rahim (2016), El-Bassiouny } \\
\text { et al. (2017), Abu-Daabes (2018), Wilson and Liu (2011), } \\
\text { Sandicki (2011), Izberk-Bilgin and Nakata (2016), Ahmad } \\
\text { (2018) Wilson (2014), Borzooei and Asgari (2015) }\end{array}$ \\
\hline Market segment & $\begin{array}{l}\text { Arham (2010), El-Bassiouny (2015), Jafari (2012), Asad } \\
\text { (1993), El-Bassiouny (2014), Khan and Janmohamed (2011), } \\
\text { Izberk-Bilgin and Nakata (2006), Wilson (2012), Abdul-Talib } \\
\text { and Abd-Razak (2013), Sandikci (2011), and Sandikci and } \\
\text { Jafari (2013). }\end{array}$ \\
\hline $\begin{array}{l}\text { Size of and } \\
\text { Opportunities in the } \\
\text { halal market/industry }\end{array}$ & $\begin{array}{l}\text { Izberk-Bilgin and Nakata (2016), Abdul-Talib and Abd-Razak } \\
\text { (2013), Ghazali and Mutum (2016), Rahim (2016), The Halal } \\
\text { Journal (July and August 2010), Tournois and Aoun (2012), } \\
\text { Abu-Daabes (2018), Alserhan (2010a), and Ghazali and Mutum } \\
\text { (2016). }\end{array}$ \\
\hline $\begin{array}{l}\text { Consumer behavior and } \\
\text { perceptions towards } \\
\text { Islamic products }\end{array}$ & Rahim (2016) \\
\hline
\end{tabular}




\begin{tabular}{|l|l|}
\hline Awareness of Halal & Rahim (2016) and Naser et al. (2013). \\
\hline Religion and religiosity & $\begin{array}{l}\text { Rahim (2016), Farhana (2014), Nasir and Periera (2008), } \\
\text { Mukhtar and Butt (2012), Ali et al. (2015), Alam et al. (2012) } \\
\text { and Pepinsky (2012). }\end{array}$ \\
\hline Price & $\begin{array}{l}\text { Rahim (2016), Jihan and Musa (2014), Shah et al. (2008), Ali et } \\
\text { al. (2017), Ahmad et al. (2013), Amin (2013), Hussin et al. } \\
\text { (2013), }\end{array}$ \\
\hline Country of Origin & $\begin{array}{l}\text { Rahim (2016), Borzooei and Asgari (2015), Ali and Darak } \\
\text { (2014), and Borzooie and Asgari (2015). }\end{array}$ \\
\hline $\begin{array}{l}\text { Halal Logo and } \\
\text { Packaging }\end{array}$ & $\begin{array}{l}\text { Rahim (2016), Aidi-Zulkarnain and Ooi (2014), Shafi et al. } \\
\text { (2013), The Halal Journal (2010), Rezai (2008), Salman and } \\
\text { Siddiqui (2011), Pazim et al. (2010), Anir et al. (2008), Aziz et } \\
\text { al. (2010), Zhari and Hakim (2010), Jihan and Musa (2014), } \\
\text { Shah et al. (2008), Omar et al. (2008), and Hussin et al. (2013). }\end{array}$ \\
\hline Media and Advertising & $\begin{array}{l}\text { Rahim (2016), Ismail and Nasiruddin (2014), Hassan and } \\
\text { Hamdan (2013), Rahim et al. (2013), Rahim et al. (2015), } \\
\text { Hussin et al. (2013), Kordnaeji et al. (2013), Ayanwale et al. } \\
\text { (2005), Amabali and Bakar (2014), Teng and Jamaliah (2013), } \\
\text { Said et al. (2014), Amin (2013), and Alotaibi (2013). }\end{array}$ \\
$\begin{array}{l}\text { Rahim (2016), Abdullah (2006), Anir et al. (2008), Ahmad et al. } \\
\text { (2013), Teng and Jamaliah (2013), Ismail and Nasiruddin } \\
\text { (2014), and Rahim et al. (2013). }\end{array}$ \\
\hline $\begin{array}{l}\text { Role of Government and } \\
\text { related organizations }\end{array}$
\end{tabular}

\section{Islamic Marketing and its perspectives}

\section{What is Islamic/halal marketing}

Islamic and halal marketing have always been used interchangeably (Rahim, 2016). Wilson (2012, p. 6) defined Islamic marketing as marketer's and consumer's acknowledgment of a "God-conscious approach" to marketing. The author further referred to Islamic marketing as "A school of thought" inspired by the "Ethical norms and values of Islam." However, it is to be noted that these schools of thought in turn reflect the way muslims are different across different cultures in the manner they connote these norms. In other words, Islamic marketing is not only concerned with "meat and money" (Wilson and Liu, 2010) but goes beyond and involves how the meat and money part are conceived of and incorporated in practice of Islamic marketing. Consistent with this, Alom and Haque (2011) cited in El-Bassiouny et al. (2017) defined Islamic marketing as an approach (emphasis added) to satisfy the needs of the customers through halal products with the mutual consent of both the buyer and seller for their temporal as well as the eternal benefit. To make this aspect of eternal benefit as part of the Islamic marketing conceptualization, Alserhan (2015) referred to Islamic marketing as marketing effort carried out by businesses or Muslims for the Muslim consumers.

In this regard, Ahmad (2018) constructed Islamic marketing as a God-consciousness perspective; it incorporates a moral boundary derived from the moral values of Islam. Following this, Rahim (2016) defined Islamic marketing as ethical marketing encompassing Islamic moral values involving a dynamic framework of both Muslims' as well as nonMuslims' engagement in marketing, thus expanding the earlier involvement of Muslims for Muslims, suggested by Alserhan (2015). 
On the other hand, Hassan et al. (2008) cited in Ghazali and Mutum (2016) defined Islamic marketing as based on the principle of value maximization, with the focus on justice for the whole society. Saeed et al. (2001) cited in Hossain et al. (2018) also proposed the same definition. Abu-Daabes (2018) suggested Islamic marketing as a means of maximizing value for muslim businesses and society regulated by Quran and Sunnah. At another instance, the author suggested Islamicmarketing to be a new competing force against conventional marketing.

El-Bassiouny et al. (2017; p. 9) proposed the hierarchy of Islamic marketing, starting from marketing targeted at muslims, understanding their needs and addressing them, to "Shariahcompliant marketing" and "Shariah-compliant marketer." Emphasizing the importance of Islamic marketing, Izberk-Bilgin and Nakata (2016) referred to halal/Islamic marketing (Shariah-compliant) as the key to approach the Muslim market and fulfilling their needs in Muslim majority as well as minority markets (Tournois and Aoun, 2012; Temporal, 2011).

In Islamic marketing, all activities of marketing have to be performed according to guidelines given in the Quran and Sunnah (Abu-Daabes, 2018; Shamsudin and Abd Rahman, 2014). Kadirov (2014) suggested that marketing practices maintaining Islamic standards would obviously need to work within a defined frame of morals best designed to promote those principles. Therefore, Muslim marketers must make sure that all the marketing activities, including promotion, distribution, product planning, etc., should be in line with the Islamic guidelines (Abdullah and Ahmad, 2010). The authors further referred to Hanafi and Sallam (1988), who proposed that six categories of moral principles of Islam, namely, trust, sincerity, truthfulness, brotherhood, justice and science and technology, should be applied to marketing activities from an Islamic perspective.

Zakaria and Abdul-Talib (2010) cited in Tournois and Aoun (2012) proposed an Islamic market-oriented cultural model arguing that the strategies for exporting products to Muslim consumers will be different (Islamic) in comparison to non-Muslims. Furthermore, the authors also stated that non-Muslims' firms need to adopt an organizational culture incorporating Islamic values, practices, structures and procedures. In case of failure to pursue, this approach could result in producing non-shariah-compliant halal products.

According to Fraedrich et al. (2018), some scholars argue that the western marketing theory is similar to the Islamic marketing theory, and the western marketing is also valid in Islamic cultures. Whereas, others argue that the Islamic theory is guided by the Holy Quran and Sunnah and is different from the western theory. However, Adnan (2013) cited in AbuDaabes (2018) argued that finding a contradiction between Islamic and traditional marketing is difficult, except by when we incorporate products that follow Islamic shariah. This implies that all marketing functions of Islamic marketing are similar to that of traditional marketing, except in the nature of product. In line with this, Wilson and Grant (2013) noted that not questioning the core inferences and functions of marketing leads to a consideration that Islamic marketing is the application of the traditional marketing mix aimed at a different target market. They, therefore, suggested that the principles of conventional marketing need to be reconsidered and re-evaluated in the context of Islamic marketing.

According to Hossain et al. (2018), as per the Holy Quran, Islamic marketing is built on two requirements, which are physiological and safety needs and relieving the demand of consumers. Al-Nashmi and Almamary (2017) noted that Islamic marketing focuses on the contemporary marketing practices and thoughts from an Islamic perspective examining the 
way Muslims' market behavior is shaped by various religious and cultural formations. Nonetheless, Hossain et al. (2018) noted Islamic marketing as an absolute and definite form of knowledge in the broader marketing context. Sula and Kartajaya (2006) cited in Arham (2010) proposed four characteristics of Islamic marketing, which are spiritualistic (business according to Islamic teachings), ethical (follow ethical teachings of Islam), realistic (no violation of Islamic principles) and humanistic (more focus on society). In this whole process of Islamic marketing, the objective cannot be isolated from Islamic principles (Arham, 2010).

\section{Macro-marketing perspective}

Abdullah and Ahmad (2010) stated that Islamic instructions ensure the protection of the interests of all parties in a transaction. Furthermore, Ghazali and Mutum (2016) also argued that sustainable marketing, green marketing and ethical marketing are compatible with Islamic marketing. Emphasizing this aspect, El-Bassiouny et al. (2017) noted that the Islamic perspective of marketing is unique in a way that it is focused on societal welfare, which is similar to macromarketing. Kadirov (2014) further reported that the macromarketing theory has more to offer than micromarketing principles, particularly to conceptualize, understand and enquire issues in the domain of Islamic marketing and proposed an Islamic macromarketing perspective along various aspects, which is briefly described hereunder.

As per Kadirov (2014), the first dimension is the "Unit of analysis," which in this case is a marketing system characterized by Islamic principles. The second dimension is "Domain/ Scope," which is the association of transformed marketing system (to comply with Islamic principles) with the society as well as the environment. The third dimension is "Orientation," which in this case is primarily the Muslim community, but may also extend to non-Muslims as well. The fourth dimension is "The ends," which indicates maximizing the good deeds, forming the basis of "hasanah" (goodness, excellence), not only in this life but also eternity (Alserhan, 2010b). The fifth dimension is "The means," which suggests facilitating the public to engage in marketing in a way of worship and worship in a form of marketing. The sixth dimension is "View of Man," which in Islamic marketing considers "Man-in-Submission," a person who is destined to have sincere concerns for others. The seventh dimension "Role of Scholars" considers scholars as people possessing the knowledge and are capable to develop Islamic marketing systems, which assist in the accomplishment of "hasanah." The eight dimensions reflects the "View of Marketing System," which suggests that this world is a temporary habitat for people. The final dimension "Essence" represents the process of enabling and improving the submission of the created to the Creator.

El-Bassiouny (2014) related the Islamic perspective of marketing to sustainability and reported that the Islamic law clearly establishes the frontier of individual rights and responsibilities to manage all facets of life, comprising all business and marketing activities along with sustaining human welfare. In line with this, Abu-Daabes (2018) noted that Islamic marketing emphasizes the association with the creature, well-being, compliance with shariah, religious belief, halal and eternal life as well. In this way, Hussnain (2011) noted that the process of Islamic marketing focuses on maximizing stakeholders' and community's wellbeing by designing and implementing strategies administered by Quran and Sunnah.

According to the Islamic paradigm, performing sustainable activities while maintaining the economic, social and environmental well-being are mandatory for Muslims and form an essential part of business activities (El-Bassiouny et a., 2017). In this form, the Islamic 
perspective of macromarketing not only covers the individual's physical and spiritual wellbeing but also considers the well-being of all other stakeholders and the society as well.

\section{Activities in Islamic Marketing}

\section{Market segment}

Islam is way of life guiding Muslims in every aspect of life (Arham, 2010). From the Islamic perspective, the main source of reference for Muslim followers is the traditions of the Prophet Muhammad (SAW) and the Holy Quran (El-Bassiouny, 2015; Jafari, 2012; Asad, 1993).

Because of this, Muslim followers presume that business as well as marketing will be affected by their religious rules (El-Bassiouny, 2014). Furthermore, Muslims look for brands that accept the values important to the Muslims and offer value that is much more than just delivery of a product (El-Bassiouny, 2015; Khan and Janmohamed, 2011). However, even though consumption is permitted, it is important to understand that excessive consumption is forbidden in Islamic texts (El-Bassiouny, 2015). The above points highlight that the consumption choices of Muslims differ from non-Muslims and thus mark the difference signifying Muslims as a separate segment.

Muslims' market as a separate market segment is also pointed out by various other authors in terms of consumption. In this line, Izberk-Bilgin and Nakata (2016) noted that the Muslims of today are more educated and are ready to engage in the "consumer culture," by pursuing a demand for renowned brands. Similarly, Wilson (2012) reported that similar to other consumer segments, Muslims love fashion and a good lifestyle, but also demonstrate identifiable and distinct attributes. Further, Abdul-Talib and Abd-Razak (2013) reported that there is worldwide awareness and a growing demand for halal products because of the growing presence of Muslim communities within communities.

Various authors highlight economic viability of Muslims' market in terms of their large population and size as a segment in the context of halal marketing. For instance, ElBassiouny (2014) noted that Muslims' population is more than one billion and portrays an important market segment in various countries of the world, which is still growing even now. Similarly, Muslims constitute around 20\% of the global population in 2015 (AbuDaabes,2018; Grim et al., 2015). In line with this, an important point been noted is that the Islamic Marketing growing Muslim population has acted as a driver of growth for the halal industry and halal marketing (Izberk-Bilgin and Nakata, 2016; Abdul-Talib and Abd-Razak, 2013; Rahim (2016).

Other few authors have also noted that the Muslims' market is as yet an untapped market segment. For instance, Sandikci (2011) reported that the interest in Islamic marketing is because of the identification of Muslims as an untapped and profitable marketing segment, with the visibility linked to the high purchasing power of muslims. Consistent with this, it is reported that the practice and research of Islamic marketing has two perspectives, of which one is the managerial perspective focusing on Muslims as a separate market segment (ElBassiouny, 2015; Sandikci and Jafari, 2013).

\section{Islamic marketing mix}

Rahim (2016) briefly discussed the marketing mix from the Islamic perspective. According to Maxim (2009), Neil Borden in 1954 presented the concept of marketing mix, which consisted of 12 variables, which were further simplified by McCarthy in 1960 in the form of 4Ps that is 
widely used even now. In this section, the discourse on marketing mix from the Islamic perspective will be presented relying chiefly on the discussion by Rahim (2016).

The products and services referred to "Halaalan Thoyyiban (good and wholesome)" should be in line with the Islamic teachings in the context of halal/Islamic marketing (p. 293, Rahim, 2016). Further, the Islamic principles (shariah) should not be violated in producing products and services, and hence should not involve any components prohibited in Islam. As an example, the Prophet Muhammad (SAW) sold fresh products that were needed by people (Arham, 2010; Trim, 2009), and prohibited to keep different qualities of products (low and high) at the same place (Arham, 2010; Al-Fatih, 2009).

Regarding pricing, Islam provides guidelines for pricing. In conventional economics, the focus of business firms is on profit maximization in setting the price. Contrarily, in Islam, pricing should consider the interest of the people (Ahmed and Rahman, 2015). According to Islamic principles, price must be fair as per the quality of the product, affordable to the society and transparently informed avoiding any confusion and deception. Arham (2010) referring to Trim (2008) reported that the Prophet Muhammad (SAW) sold the products at a price affordable for the market. For the halal products, consumers may be willing to pay more price as far as they are confident that the product is halal. However, Islam prohibits hoarding with the purpose of inducing high prices of the products.

As far as promotion is concerned, principally, in Islam, it should neither be excessive nor deceptive. Excessive in this case refers to advertising that associates products and services with a luxurious lifestyle, while deceptive refers to advertising that associated products and services with their social acceptability. According to Ghazali and Mutum (2016), deception in marketing is strictly prohibited in the Holy Quran. Islam prohibits the act of overpromising in promotion (Arham, 2010; Trim, 2008) and emphasizes promotion within the ethical frame to avoid perception that the customer is being deceived (Arham, 2010). For instance, Islamic credit cards should not be associated with maximizing satisfaction, while modest fashion should not be promoted with female models not covered properly.

Regarding place/distribution channel, Islam prohibits marketers to sell haram products in their distribution channel as well as prohibits hoarding products create greater demand. Furthermore, monopoly is prohibited in Islam (Arham, 2010), thereby controlling the distribution channel with the intent of setting high prices (Arham, 2010; Trim, 2009) is considered prohibited.

\section{Target and approach}

Islamic marketing is a pool of information that can enhance marketing strategies by avoiding conflicts, providing deep insights and bringing opportunities within the Muslims' markets to light (Abu-Daabes, 2018). The author further suggested that the details could be used to introduce new products and services in muslims' markets for satisfying their needs by incorporating the Islamic values and principles. According to Sandikci (2011), the term Islamic marketing implies that it approaches Muslim consumers and uses specific resources and tools relevant to appeal to a specific Muslims' market. This has resulted in the availability of products in markets specifically positioned as halal and targeted to Muslim consumers.

Wilson (2012) added that Islamic marketing can equally be applied to Muslims and nonMuslims. Reinforcing this, Ahmad (2018) and Wilson (2014a, 2014b) noted that it is not 
necessary to be a Muslim for being Islamic within the marketing and consumption boundaries. This indicates that non-Muslims can also consume halal when it comes to consumption. Consequently, because of the health and purity elements of halal food and beverages, non-Muslims are also attracted to halal products (Abdul-Talib and Abd-Razak, 2013; Hashim and Othman, 2011), resulting in increasing their acceptance among nonMuslims (Muhammad et al., 2009). According to El-Bassiouny (2015), practitioners have used this trend and are communicating their products as healthy to consumers who are health conscious. Contrary to this, Kadirov (2014) reported that certain Islamic concepts like Islamic marketing, finance, etc. can have practical relevance if targeted at the muslims only.

\section{Opportunities, Controversies and Challenges in Islamic marketing}

\section{Opportunities in the halal market/industry}

According to Izberk-Bilgin and Nakata (2016), the halal market has grown significantly over the past few years and offers various opportunities in various business sectors, particularly in the consumer goods market of everyday use like cosmetics, toothpaste, medicine, etc. purchased and consumed on a regular basis. Abdul-Talib and Abd-Razak (2013) also reported that because of the huge growth in the global halal market, it is opening innumerable opportunities for business firms in various industries, and as such, the halal industry has a huge growth potential. Realizing this huge potential of Islamic businesses, the interest in Islamic marketing is increasing (Ghazali and Mutum, 2016). According to the World Halal Forum, the global halal industry excluding banking sector was estimated to be worth US\$2.3tn in 2010 (Rahim, 2016; The Halal Journal, July and August, 2010). Rahim (2016) further reported that finance and food sectors have registered the largest volumes due to the awareness of consumers regarding the availability of such products.

In line with this thinking, Al-Bayan (2010) cited in Tournois and Aoun (2012) reported that the increase in Muslim population globally provides various opportunities as well as challenges to tap into the huge shariah-compliant (halal) market, which is recording the highest growth in the world (Abu-Daabes, 2018; Alserhan, 2010a). Because of the large size and high growth rate, not only Muslim manufacturers but also non-Muslim manufacturers are engaging in the halal industry. Ghazali and Mutum (2016) stated that the growing interest in Islamic business, particularly marketing, is not surprising, and a number of booming businesses with halal branding are seen in different areas, including food, finance, fashion, education and airlines as well.

\section{Controversies in Islamic marketing}

There are certain controversies in Islamic marketing in its present form causing confusion in its understanding. In this line of argument, Abu-Daabes (2018) reported that Islamic marketing is being criticized for promoting and marketing Islam unduly, thus creating an overselling. As such, Islam as a religion is being underlined to some of the factors contributing to the exaggeration in presenting Islam, overwhelming details of Islam, complicated display of Islamic principles and values. Furthermore, some companies are using Islamic marketing by exploiting religious sentiments of consumers and even supplying products that lack the Islamic attributes for halal only to generate profits. In this regard, AbuDaabes (2018) noted that Islam does not prohibit making profits, but the problem is confining Islam merely to be a "marketing tool" (Jafari, 2012).

\section{Issues and challenges in Islamic marketing}


The Islamic marketing literature also highlights various issues and challenges associated with the concept of Islamic/halal marketing. Also, Rahim (2016) considers that the halal industry is becoming more complex due to the involvement of other components in the industry like shariah governance, halal assurance, logistics, etc. Furthermore, despite the opportunities in the halal industry, approaching the muslim consumers' segment possessing various complexities like cultural, geopolitical and operational barriers is a challenge for marketers (Izberk-Bilgin and Nakata, 2016). In this regard, one of the prominently discussed issue is the difference within the Muslims and the diversity in their definition and interpretation of halal. This is due to the reason that Muslims involve themselves in the practice of Islam, which is the result of interpretation of injections, which are considered ambiguous and are based four schools of jurisprudence thought proposing a specific set of guidelines (Rahim, 2016).

According to Sandikci (2011), even though Muslims are considered homogeneous sharing similar characteristics, there are inter-differences within the Muslims and Muslims from different schools perceive and interpret halal differently, making it very difficult to classify halal markets in a generalized manner. In this line of argument, Ahmad (2018) noted that behaviors of Muslims are dependent on time and place. Jafari (2012) reported that due to the dynamic level of religiosity, people interpret their history, identity, religion as well as political dynamics differently, thereby considering Islam as monolithic is a big mistake. For this reason, Abu-Daabes (2018) suggested that Islamic marketing needs to develop an understanding of the dynamics and practices of Muslims in specific contexts as well as defining these contexts and all the actors that shape the Muslim markets. So, Islamic marketing is required to be understood and viewed from different viewpoints and at different levels (Kadirov, 2014; Hussnain, 2011).

Abdul-Talib and Abd-Razak (2013, p. 189) reported three major hurdles in the practice of halal marketing. These include "harmonization of standards; information scarcity and industrial innovation challenges." The authors state that there are diverse halal standards not only across markets but also across different industries, causing confusions for marketers. The issue of diverse standards has also been reported by Izberk-Bilgin and Nakata (2016). In terms of harmonization, they report the existence of multiple interpretations of halal in the diverse Muslim community creating confusion for firms looking to approach the halal market. Furthermore, the absence of uniform halal certification and logo also creates a problem for firms engaged in global supply chain or exporting to various countries. Secondly in terms of lack of information scarcity, it affects suppliers in terms of opportunities available in the market, and in consumers, about the existence of a halal category of products. The final barrier for the halal industry reported by Abdul-Talib and Abd-Razak (2013) is the question of industrial innovation, whether the industry is able to create new value and new satisfaction for the customer (Drucker and Maciariello, 2004).

\section{Islamic Principles}

\section{Islamic guidelines}

Muslims agree that Islam is a supernatural reality that supersedes all (Jafari, 2012; Jafari and Suerdem, 2012). While shariah (Islamic guideline) is a way of life based on the Holy Quran and Sunnah as well as rational reasoning, including Ijtihad (analogical reasoning), Istihsan (juristic preference), Istishab (pre-consumption of continuity) and Ijma (consensus among scholars) (Rahim, 2016; Kamali, 2008). Besides these, Tawhid (belief in the oneness of Allah) is the most critical concept in Islam (Arham, 2010; Alhabshi, 1987; Haneef, 1997), which can influence the marketing process (Arham, 2010). Emphasizing this, Jafari (2012) 
reported that Islam influences the daily lives of Muslims, including business, consumer behavior, ethics and inter-personal relationships as well.

Regarding business and commercial activities, Islam aims to find a balance between commercialism and humanitarianism as well as profit and social responsibility (Fraedrich et al., 2018). Furthermore, from the Islamic perspective, business is considered an essential part of human life so critical that Allah ordained the Prophet Muhammad (SAW) as a successful businessman prior to his prophetic life (Arham, 2010; Antonio, 2007; Trim, 2009). Arham (2010) further stated that Islam guides its followers to earn wealth in a reasonable way as Allah mentioned in the Holy Quran. Following this, Ghazali and Mutum (2016) noted that Islam encourages economic activities and does not prohibit wealth creation, but various Quranic verses and Ahadith (sayings) of the Prophet Muhammad (SAW) opposes the materialism for its accumulative focus.

Guidelines regarding all activities are administered by "Maqasid al-Shariah (Objectives of Shariah)," which are designed to provide benefits and protect from harm (Rahim, 2016, p. 274; Al-Mubarak and Osmani, 2010).

\section{Halal}

Halal means anything that is permissible under the Islamic shariah (Izberk-Bilgin and Nakata, 2016). Haram is the antonym of halal and means anything that is prohibited and anything [1] that is not specifically mentioned as halal or halal is referred to as syubhah or makrooh (Rahim, 2016). He further stated that usually halal is wrongly understood to be refraining from alcohol, pork and meat of animals not slaughtered according to Islamic shariah and is only restricted to food, whereas in reality, halal applies to all consumables. Similarly, according to El-Bassiouny et al. (2017), the term halal concerns a portfolio of products and services and represents an Islamic lifestyle considering what is permissible and nonpermissible. In this line of argument, according to Abu-Daabes (2018), some Muslims restrict halal only to food, while others consider it as a way of life. Whereas, the religion of Islam refers to everything as halal unless stated differently in the Quran (El-Bassiouny et al., 2017; Wilson and Liu, 2011). In other words, even though halal is considered to have a prime focus in Islamic markets (Abu-Daabes, 2018), but the term halal is very complex and dynamic because of the way it is understood and interpreted which differ fromculture to culture (Sandikci, 2011).

To undertake a better understanding of the concept, it needs to be looked at from a wider scope than stressing cleanliness in goods. For halal also refers to conscience as well as behavior asking Muslims to perform good deeds and choose moral alternatives, which makes halal consistent with sustainability and considers corporate social responsibility (CSR) within its scope of activities (Izberk-Bilgin and Nakata, 2016). Halal is suggested to signify the highest degree of dedication to ethical and moral practices (Ahmad, 2018; Wilson, 2014a, $2014 \mathrm{~b}$ ). Because of these reasons, the terms of "halal" and "Islamic" carry elements of a brand and provides marketers with an advantage (Rahim, 2016; Borzooei and Asgari, 2015). In line with this, Wilson and Liu (2010) noted that business firms seem to have recognized the potential of as a brand element, which can help business firms increase their market share. Further, Rahim (2016) reported that consumers expect high standards from these terms making marketers responsible to pay attention to the halal products and assure that the products are in line with the shariah principles and certified halal only by proper regulatory authorities. 


\section{Determinants of consumer behavior and awareness toward Islamic products}

Rahim (2016) discussed the perceptions and behavior of consumers toward Islamic products, including finance and consumables. According to him, awareness plays an important role in purchasing halal products and significantly contributes to a successful economy. There are various factors for increasing awareness of halal products. A few factors that play a significant role are discussed in the following section, including the role of media and marketing as well as the government and related organizations.

\section{Media and advertising}

Media coverage is a very effective tool in developing awareness of a specific product (Rahim, 2016). Media coverage refers to the various information sources, including television, newspapers, radio, internet, social media and various others (Ismail and Nasiruddin, 2014). For halal products, media advertising is perceived as being addressed to Muslims and their needs (Hassan and Hamdan, 2013). Rahim et al. (2013) and Rahim et al. (2015) evidenced a positive relationship of media with awareness and perceptions toward products and sources. Further, Hussin et al. (2013) found that advertising plays a mediating role in price-purchase intentions for halal cosmetics. Similarly, Kordnaeij et al. (2013) found a significant and positive relationship of advertising and purchase of halal products.

Ayanwale et al. (2005) in their study reported that majority of the respondents surveyed were aware of a specific brand because of advertising. Similarly, Ambali and Bakar (2014) showed that majority of the consumers gain information about halal products through advertisement from various channels. Further, Teng and Jamaliah (2013) manifested internet as the most significant channel of information for halal products followed by television and advertising, and other channels of information like newspapers, store display, radio, etc. Amin (2013) suggested the use of social media like Facebook and Twitter for promoting Islamic financial products. In line with this, Alotaibi (2013) also found a positive relationship between Twitter and awareness of Islamic banking products in Saudi Arabia. Whereas, on the contrary, Said et al. (2014) found in their study that above $40 \%$ respondents obtained information about halal products from specialized magazines and $32 \%$ received this information from newspaper.

\section{Role of government and related organizations}

Evidence exists of the contribution of related organizations in developing awareness about halal products among Muslim consumers (Rahim, 2016). The findings of the study of Abdullah (2006) reported that majority of the respondents (marketers) agreed that government initiatives and support can help in developing the halal industry. Furthermore, the study of Anir et al. (2008) carried out in Klang valley confirmed that getting updates from the authorities about the halal status of manufacturers is important for consumers. In line with this, Ahmad et al. (2013a, 2013b) reported that involvement of government significantly and positively affects the perception toward halal products.

On the other hand, few studies also report that involvement of the government does not contribute much to the perceptions of and in creating awareness for halal products. For instance, Teng and Jamaliah (2013) reported that campaigns by the government contribute $5.9 \%$ as the channel of information about halal cosmetics. Similarly, Ismail and Nasiruddin (2014) reported that the contribution of government's campaigns as an impersonal channel of information is only $5.5 \%$.

\section{Religion and religiosity}


Religion and religiosity play a vital role in determining the Muslims' attitude toward halal products. There are a number of studies that have highlighted the role of religion and religiosity in influencing the purchase of halal products. For instance, Farhana (2014) provided evidence that proved that in Bangladesh, religiosity plays an important role in purchase of Islamic finance products. Similarly, Nasir and Pereira (2008) argued for the existence of direct relationship between religiosity and concern for halal products in Singapore. Furthermore, Mukhtar and Mohsin Butt (2012) found that religiosity significantly affects intentions to select halal products. To further extend the argument, Ali et al. (2017) found that religious belief significantly affects consumer intentions in Pakistan for Islamic home financing, while Alam et al. (2012) found similar results in Malaysia. Contrarily, Pepinsky (2013) found that religiosity does not influence behavior toward Islamic finance in Indonesia.

\section{Price}

According to Rahim (2016), halal products' price should not affect consumers because of the reason that price of products is based on brand equity consideration. Furthermore, the author stated that the halal logo/symbol has no direct impact of the product. Similarly, according to Jihan and Musa (2014), price influences the purchase decision of halal cosmetics only, if the product is of good quality. In other words, the product quality and brand consideration have a more pronounced impact on price and purchase decisions. In line with this, several studies have reported the influence of price on consumer behavior in the context of halal products differently. For instance, contrary to the no price effect of Halal certification, Shah et al. (2008) reported price as one of the factors influencing the perceptions of Muslims that halalcertified products are relatively expensive. They further stated that customers perceived halalcertified products as costlier than non-certified products and associated lower price with lower quality. Similarly, Hussin et al. (2013) suggest that despite being halal-certified, customers will not buy the product if its price is high.

Ahmad et al. (2013a, 2013b) found that consumers in the Klang Valley of Malaysia select food franchises based on price and taste irrespective of halal certification. Furthermore, for Islamic financial products, Amin (2013) reported that consumers perceived Islamic credit cards as expensive, which can impede the use of Islamic credit cards. Similarly, Ali et al. (2017) found that in Pakistan, consumers perceived cost of credit card as negatively associated with its usage, indicating that the cost factor does not impede Islamic credit card usage. The various studies cited in the section indicate contradictory perceptions toward the effect of price to different products. Therefore, this needs further research as price factor in relation to halal products works in some product categories and not in others.

\section{Country of origin}

Country of origin represents the country where a product is manufactured (Rahim, 2016). A number of studies propose country of origin as a factor affecting consumer buying behavior. In the context of halal, consumers may prefer to buy products from countries that have prestige in the halal production (Borzooei and Asgari, 2015). They reported that Middle Eastern consumers preferred Saudi Arabian products as compared to Malaysian products because of the perception that Saudi Arabia has stiff shariah compliance. Ali and Darak (2014) found that in the UAE, consumers perceive Malaysian products halal and of high quality. On the contrary, furthermore, Rahim (2016) noted that consumers from Middle East also prefer products from other Muslim countries as well. Whereas, Malaysian consumers prefer products manufactured in Singapore as compared to Thailand, while also considering Chinese halal products as reliable. On the other hand, consumers in Africa and Middle East do not hesitate to buy Chinese products. 


\section{Halal logo and packaging}

Awareness about halal induces manufacturers to obtain halal certification (Rahim, 2016), and the businesses use halal logo as part of their branding and marketing strategy. Halal logo in other words is used to gain trust of the consumers (Aidi-Zulkarnain and Ooi, 2014; Shafii et al., 2013). Executive Director of Totalife Malaysia and Singapore, Frederick Ng said that by using halal certification, they have managed to gain consumers' confidence and demand for their products and services in Malaysia, Singapore and China (The Halal Journal, 2010) have increased.

Various studies reported a positive attitude and perception toward halal-labeled products (Rezai, 2008; Salman and Siddiqui, 2011). Pazim et al. (2010) found that consumers in Kota Kinabalu (Malaysia) are very conscious about the halal logo. Moreover, various other studies have highlighted the importance of halal logo for consumers, including Anir et al. (2008), Aziz et al. (2010). Further, Ambali and Bakar (2014) reported that the halal logo has contributed in creating awareness of halal consumption in Muslim consumers. Similarly, consumers are reported to have become more concerned about halal, and they look for products that satisfy their needs as well as providing them with peace of mind (Jihan and Musa, 2014).

Shah et al. (2008) reported a positive customers' attitude toward halal-labeled products but on observation, only $18 \%$ were found looking for halal label before purchasing a product. This is perhaps because of the perception that in Muslims-majority country, the available products are assumed to be halal. Similarly, Omar et al. (2008) reported in a study carried out in Kelantan, Malaysia, that the consumers perceived all available products to be halal, and as such, the halal logo is no issue for them. Hussin et al. (2013) noted that halal certification only works as the convincing element for the consumers not as determinant of product purchase.

\section{Summary}

To sum up, the study aims to provide an understanding of Islamic marketing based on the previous literature in the subject area of Islamic marketing. In this regard, an integrative review approach was used, and the data were extracted in form of themes. The themes were organized around a set of dimensions having relevance to the phenomenon of interest and contributed toward developing an understanding of Islamic marketing, which resulted in five major themes comprised of sub-themes discussed above. These include Islamic marketing and its perspectives, activities in Islamic marketing, opportunities, controversies and challenges in Islamic marketing, Islamic principles, determinants of consumer behavior and awareness toward Islamic products. The themes are illustrated diagrammatically in Figure 1.

Figure 1: Themes emerged from the review

Islamic Marketing and Its Perspectives 


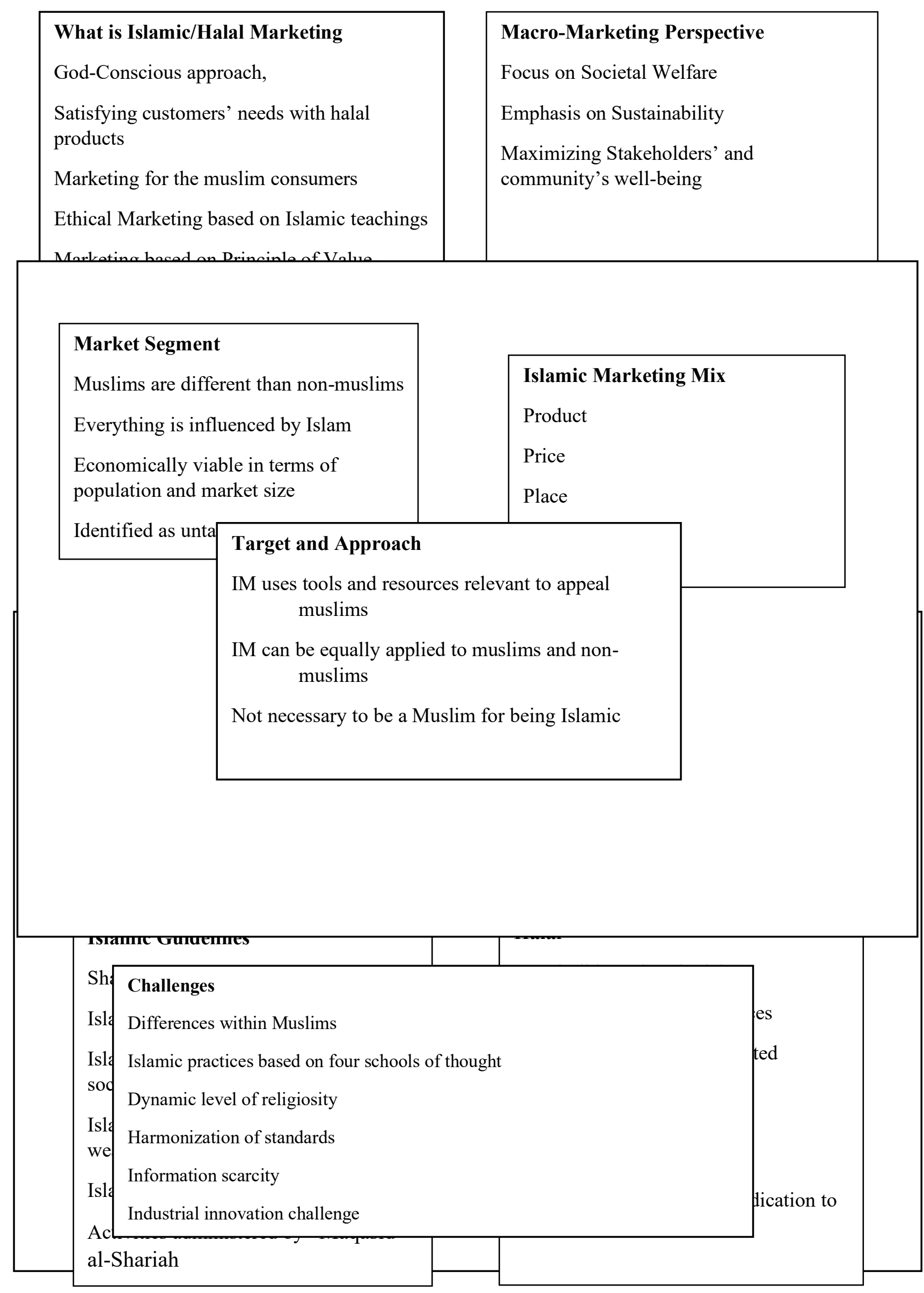




\section{Determinants of Consumer Behavior and awareness}

towards Islamic Products

Media and Advertising

Role of Government and related

organization

Religion and religiosity

Price

Country of Origin

Halal Logo and Packaging

\section{Discussion and conclusion}

The present study reviewed and integrated the previous literature related to Islamic marketing. The study provided a glimpse of the different concepts relevant to Islamic marketing, which have been discussed in the literature. The present section discusses the results of the study.

As the study findings suggest, various authors have attempted to define and explain the meaning of Islamic marketing. In this way, different authors have provided different perspectives and viewpoints of Islamic marketing. For instance, Islamic marketing is conceptualized as a God-conscious approach to marketing. Furthermore, a few suggest that Islamic marketing is satisfying customers' needs with halal products. Few other perspectives include conceptualizing Islamic marketing as marketing for Muslim consumers, ethical marketing based on Islamic teachings and considered as a value maximization approach. The variety in definitions of Islamic marketing indicates that there is no consensus among scholars with regard to a definition of Islamic marketing. However, the variety of definitions do indeed highlight the important aspects of the principles of Islamic marketing.

Moreover, the literature provides another striking perspective of Islamic marketing in terms of a macro-marketing conceptualization. In this regard, various authors have noted that 
Islamic marketing is more akin to macromarketing. The striking points discussed from this aspect include the emphasis on societal welfare, sustainability and maximizing the wellbeing of stakeholder and community as a whole. The macromarketing perspective dictate that Islamic marketing encompasses the concept of overall welfare of society.

Another major theme of the study is the activities in Islamic marketing, including market segmenting, Islamic marketing mix and target market and approach. A frequently discussed area in the Islamic marketing literature is the importance of the market segment. In this regard, though the literature notes that Muslims are different from non-Muslims, very little has been explained about the points of difference. On the other hand, the economic viability of the Muslim consumers' market in terms of their large population and purchasing power have largely been discussed. Furthermore, the literature discusses various components of Islamic marketing mix, which include the 4Ps (product, price, place and promotion) of traditional marketing, but imbued with the Islamic principles in terms of implementing these. Even though the literature has discussed the 4Ps of traditional marketing in their Islamic contextualization, the Islamic principles still lack detail explanation of the real concerns that need to be dealt with in terms of Islamic principles.

Moreover, the authors have further attempted to explain the target markets, which can be approached using value proposition based on Islamic marketing. In this regard, it is noted that Islamic marketing uses approaches and resources that are relevant to appeal to Muslims only. On the other hand, it is suggested that Islamic marketing is not exclusive to Muslims but could also be relevant to non-Muslim consumers.

Furthermore, the literature has also discussed the opportunities, controversies and challenges associated with Islamic marketing. Islamic marketing provides various opportunities to the marketers. This is because of the reason that the halal industry has grown significantly for the past few years and is now a trillion dollars industry. Moreover, the halal industry is considered to have the highest growth rate.

However, there are also certain controversies associated with Islamic marketing that include the complex interpretation of Islam and with merely using Islam as a tool for marketing to earn profit. In this regard, it needs to be understood that Islamic marketing is not merely a tool to reap profits by sentimentally addressing Muslims in the name of religion, but an allencompassing phenomenon that applies Islamic principles to the marketing process to satisfy needs of Muslim consumers. As far as the challenges are concerned, the prominent issue highlighted in the literature is the differences in definition of halal and interpretation of what constitutes halal among Muslims. Another challenge is that the halal criteria also differ for products of different nature. It is further noted that Muslims in different regions have different levels of religiosity as well as diversity in religious practices, making it difficult for Islamic marketing practitioners to understand their behavior to apply a generalizable understanding across market segment and products.

Islam is noted to be the most significant factor governing a Muslim's life. It is important to understand that the Holy Quran and Sunnah act as guidelines in the life of a Muslim and govern every aspect of the Muslims' life, including behavior, ethics, as well as inter-personal relationships, etc. Furthermore, Islam has also provided a guideline for conducting business. An example of this can be found by looking at the Holy Prophet (SAW), who has also been a businessman. As the business practices are concerned, Islam prohibits a materialistic focus 
and emphasizes a fair earning of wealth. In this way, Islam finds a balance between profit and social responsibility.

Besides these, halal and haram have also been discussed in the literature to some extent. Halal concerns products and services and means everything that is permissible according to Islamic teachings. Whereas, haram means anything that is prohibited. Halal not only stresses cleanliness but also the highest degree of dedication to ethical and moral practices. However, the concept of halal is very complex and dynamic, as there are differences in the interpretation of halal among Muslims.

Finally, some studies have noted the determinants of consumer behavior and awareness toward Islamic products and services. The key determinants include media and advertising, role of government and related organizations, religion and religiosity, price, country of origin, halal logo and packaging. Media and advertising are suggested to be the prime Islamic marketing information seeking channels regarding Islamic products. Moreover, government and other organizations play a vital role in developing awareness and influence consumers' perceptions toward Islamic products. Similarly, religion and religiosity have been found in various studies to influence purchase of halal products and services. Contrarily, one study reported that religiosity does not affect behavior toward Islamic finance.

Moving forward, studies investigating the impact of price on behavior toward Islamic products also reported mixed results (positive and negative effect). Further adding, country of origin involves an element of trust in the context Islamic products. In this regard, consumers have varying perceptions for products from different countries of origin. Finally, halal logo and packaging is suggested to be a part of the branding and marketing strategy for businesses. Halal logo has helped businesses to gain consumers' confidence, thereby influencing consumer behavior toward Islamic products.

\section{Implications for research and practice}

As the study findings suggest, different authors have provided different perspectives of Islamic marketing. It is also noted that the interpretations and practices of Islam differ from place to place. Therefore, future research needs to assess the different interpretations of Islam, and as such, their implications for Islamic marketing. Furthermore, previous literature has emphasized Islamic marketing as an approach based on segmentation. Therefore, future studies need to move beyond the segmentation aspect and explore the underlying principles of Islamic marketing in detail to prevent using Islam merely as a marketing tool. Moreover, future research also needs to explore the Islamic marketing mix and differentiate its boundaries from traditional marketing.

Furthermore, the study findings suggest that the definitions of halal are culturally diverse as well as differ across industries and products. Similarly, the levels of religiosity also differ among Muslims. Therefore, future research needs to explore and understand the cultural differences in the definitions of halal and differences in religiosity among Muslims as well. Furthermore, future studies can also use Hofstede's cultural dimensions theory and work on the application of Hofstede's cultural dimensions in the context of Muslims as consumers, which will help in further refining the presence of religiosity as different from spirituality. Finally, future studies could also study the halal standards for different products and services. The study also provides various implications for marketers. 
Marketing managers need to understand the Islamic standards beyond Muslims demographics in varied regions or parochial reiteration of the pillars of Islam. There are inter-differences among Muslims due to the school of thought they follow as well as cultural and geographical influence, which shape their definition of halal. Managers, therefore, need to understand such differences and develop strategies accordingly. The study findings indicate that advertising plays a vital role in creating awareness and as such affecting consumers' behavior toward halal products. Marketing managers, therefore, can make effective use of advertising through various channels to create awareness of halal products and as such boost consumption of their products.

Furthermore, Islamic marketing managers can find the cultural branding strategy of Holt's (2004) beneficial to develop their own marketing strategies. In the end, Islamic ethics (e.g., giving, generosity and compassion to the needy or poor) demonstrate resonating with the belief of corporate social responsibility. Muslim's entrepreneurs and managers of multinational companies (MNCs) can share and learn from each other and facilitate sustainable and more effective benefits to the communities.

\section{The limitation and future directions for research}

Like other studies, this integrative literature review has some limitations. These limitations also present opportunities for future research areas. The first limitation is from the methodology undertaken. The articles generated may not have comprehensively covered all the themes or were not sufficiently detailed in the contents. For example, where consumer behavior was touched upon major details in this area are missing limited by the method of identifying the relevant articles and journals. A more comprehensive coverage could be undertaken through a meta-analysis to help ascertain the present status of the Islamic marketing theory. However, this present initiative forms the basis on which future studies can be built.

Second, where themes have been identified, their direct or indirect relationship with Islamic marketing and even their inter-relationships are not being clearly established. This may point to the need of further developing construct measurements of the noted themes and then test these for their associations and inter-relationships, thus advancing the formalization of the theory of Islamic marketing.

Third, an Islamic theory-based review can also be conducted in Islamic marketing context to help identify themes and concepts that have as yet not been identified from the Islamic theory perspective, and this could involve an interview-based approach to collect qualitative data from religious scholars to further illuminate the theoretical concepts that have been drawn from the integrative literature review or from the proposed meta-analysis. This will help ground the Islamic marketing theory in Islamic traditions and practice.

\section{References}

Abdullah, A. N. (2006). Perception and awareness among food manufacturers and marketers on halal food in the Klang Valley. Unpublished M. Sc. thesis, Universiti Putra Malaysia, Malaysia.

Abdullah, K., \& Ismail Ahmad, M. (2010). Compliance to Islamic marketing practices among businesses in Malaysia. Journal of Islamic Marketing, 1(3), 286-297. 
Abdul-Talib, A. N., \& Abd-Razak, I. S. (2013). Cultivating export market oriented behavior in halal marketing: Addressing the issues and challenges in going global. Journal of Islamic Marketing, 4(2), 187-197.

Abu-Daabes, A. (2018). Islamic marketing paradoxes: a way to understand it again.... Journal of Islamic Marketing, 9(2), 329-337.

Ahmad, N. A., Abaidah, T. N., \& Yahya, M. H. A. (2013, March). A study on halal food awareness among Muslim customers in Klang Valley. In The 4th International Conference on Business and Economic Research (4th icber 2013) Proceeding (Vol. 1074).

Ahmad, M., Kadir, S. A., \& Salehuddin, N. A. (2013). Perceptions and behavior's of Muslims and Non-Muslims towards halal products. Journal of Social and Development Sciences, 4(6), 249.

Ahmed, S., \& Rahman, M. (2015). The effects of marketing mix on consumer satisfaction: A literature review from Islamic perspective. Turkish Journal of Islamic Economics, 2(1), $17-$ 30 .

Ahmad, N. (2018). Toward advancing debates on Islamic marketing: a renewed perspective. Journal of Islamic Marketing, 9(1), 152-166.

Aidi-Zulkarnain, M. N., \& Ooi, S. K. (2014). Tapping into the lucrative halal market:

Malaysian SMEs perspective. International Journal of Business and Innovation, 1(6), 12-22.

Alam, S. S., Janor, H., Zanariah, C. A. C. W., \& Ahsan, M. N. (2012). Is religiosity an important factor in influencing the intention to undertake Islamic home financing in Klang Valley. World Applied Sciences Journal, 19(7), 1030-1041.

Al-Bayan. (2010). The global halal market worth 2.1 trillion US dollars. Al Bayan, (10955), 17.

Alhabshi, S.O. (1987), "The role of ethics in economics and business", Journal of Islamic Economics, Vol. 1 No. 1, pp. 1-15.

Ali, M., Raza, S. A., Puah, C. H., \& Karim, M. Z. A. (2017). Islamic home financing in Pakistan: a SEM-based approach using modified TPB model. Housing Studies, 32(8), $1156-$ 1177.

Ali, R., \& Darak, R. A. (2014). Competitiveness of Malaysian fresh agriculture and agrobased products in global markets: A casestudy in the United Arab Emirates. Economic and Technology Management Review, 9(3), 93-101.

Al-Mubarak, T., \& Osmani, N. M. (2010, October). Applications of Maqasid al-Shari'ah and Maslahah in Islamic Banking practices: An analysis. In International Seminar on Islamic Finance in India (pp. 4-6).

Al-Nashmi, M. M., \& Almamary, A. A. (2017). The relationship between Islamic marketing ethics and brand credibility: A case of pharmaceutical industry in Yemen. Journal of Islamic Marketing, 8(2), 261-288.

Alom, M. M., \& Haque, M. S. (2011). Marketing: an Islamic perspective. World Journal of Social Sciences, 1(3), 71-81.

Alotaibi, M. S. (2013). The impact of twitter on Saudi banking sectors in the presence of social media: an evaluative study. International Research: Journal of Library and Information Science, 3(4).

Alserhan, B. A. (2010b). On Islamic branding: brands as good deeds. Journal of Islamic Marketing, 1(2), 101-106.

Alserhan, B. A. (2010a). Islamic branding: A conceptualization of related terms. Journal of Brand Management, 18(1), 34-49. 
Alserhan, B. A. (2015). The principles of Islamic marketing. Surrey: Ashgate Publishing, Ltd Ambali, A. R., \& Bakar, A. N. (2014). People's awareness on halal foods and products: potential issues for policy-makers. Procedia-Social and Behavioral Sciences, 121, 3-25. Amin, H. (2013). Factors influencing Malaysian bank customers to choose Islamic credit cards: empirical evidence from the TRA model. Journal of Islamic Marketing, 4(3), 245-263.

Anir, N. A., Nizam, M. N. M. H., \& Masliyana, A. (2008, May). RFID tag for Halal food tracking in Malaysia: users perceptions and opportunities. In WSEAS International Conference. Proceedings. Mathematics and Computers in Science and Engineering (No. 7). World Scientific and Engineering Academy and Society.

Arham, M. (2010). Islamic perspectives on marketing. Journal of Islamic Marketing, 1(2), 149-164.

Asad, T. (1993), "The Construction of Religion as an Anthropological Category", in Asad, T. (Ed.), Genealogies of Religion: Discipline and Reasons of Power in Christianity and Islam, Johns Hopkins University Press, Baltimore, MD.

Ayanwale, A. B., Alimi, T., \& Ayanbimipe, M. A. (2005). The influence of advertising on consumer brand preference. Journal of social sciences, 10(1), 9-16.

Aziz, A., Amin, M., \& Isa, Z. (2010, October). The perception to choose Halal Cosmetics products: An empirical study for Malaysian consumer. In 6th International Conference on Business, Management and Economics. Turkey: Yasar University.

Borzooei, M., \& Asgari, M. (2015). Country-of-origin effect on consumer purchase intention of halal brands. American Journal of Marketing Research, 1(1), 1-10.

Coombes, P. H., \& Nicholson, J. D. (2013). Business models and their relationship with marketing: A systematic literature review. Industrial Marketing Management, 42(5), 656664.

Dangelico, R. M., \& Vocalelli, D. (2017). "Green Marketing": an analysis of definitions, strategy steps, and tools through a systematic review of the literature. Journal of Cleaner production, 165, 1263-1279.

Drucker, P.F. and Maciariello, J.A. (2004), The Daily Drucker: 366 Days of Insight and Motivation for Getting the Right Things Done, HarperBusiness, New York, NY.

El-Bassiouny, N. (2014). The one-billion-plus marginalization: Toward a scholarly understanding of Islamic consumers. Journal of Business Research, 67(2), 42-49.

El-Bassiouny, N. (2015). Where is "Islamic marketing" heading?: A commentary on Jafari and Sandikci's (2015)“Islamic" consumers, markets, and marketing. Journal of Business Research, 69(2), 569-578.

El-Bassiouny, N. M., Wilson, J. A., \& Esmat, S. (2017). An Islamic macromarketing perspective on sustainability. Journal of Islamic Marketing, 8(2), 187-203.

Farhana, T. N. (2014). Religiosity, generational cohort and buying behaviour of Islamic financial products in Bangladesh. PhD thesis, Victoria University of Wellington.

Fraedrich, J., Althawadi, O., \& Bagherzadeh, R. (2018). A comparative analysis of the UN declaration, global business compact, and religious morals in determining global values for business and their application to Islamic marketing. Journal of Islamic Marketing, 9(4), 913934.

Ghazali, E., \& Mutum, D. S. (2016). Islamic marketing: Compatibility with contemporary themes in marketing. In Advances in Islamic finance, marketing, and management: An Asian perspective (pp. 213-222). Emerald Group Publishing Limited.

Grim, B., Johnson, T., Skirbekk, V., \& Zurlo, G. (2015). Yearbook of international religious demography 2015. Brill. 
Hanafi, A. A., \& Sallam, H. (1988). Business ethics: an Islamic perspective. In Proceedings of the Seminar on Islamic Principles of Organizational Behavior (International Institute of Islamic Thought, Herndon, VA).

Haneef, M.A.M. (1997), "Islam, the Islamic worldview, and Islamic economics", IIUM Journal of sEconomics and Management, Vol. 5 No. 1, pp. 39-65.

Hassan, A., Chachi, A., \& Abdul Latiff, S. (2008). Islamic marketing ethics and its impact on customer satisfaction in the Islamic banking industry. Journal of King Abdulaziz University: Islamic Economics, 21(1).

Hassan, S. H., \& Hamdan, H. (2013). Experience of non-Muslim consumers on halal as third party certification mark in Malaysia. Asian Social Science, 9(15), 263.

Hemsley-Brown, J., \& Oplatka, I. (2006). Universities in a competitive global marketplace: A systematic review of the literature on higher education marketing. International Journal of public sector management, 19(4), 316-338.

Holt, D. (2004), How Brands Become Icons: The Principles of Cultural Branding, Harvard Business School Press, Boston, MA.

Hossain, M. S., Yahya, S. B., \& Kiumarsi, S. (2018). Islamic marketing: bridging the gap between research and practice. Journal of Islamic Marketing, 9(4), 901-912.

Hussin SR., Hashim, H., Yusof, R. N., \& Alias, N. N. (2013) Relationship between Product Factors, Advertising, and Purchase Intention of Halal Cosmetic. VOL. 21 (S), 85.

Hussnain, S. A. (2011). What is Islamic marketing. Global Journal of Management and Business Research, 11(11), 101-103.

Ismail, F. R. B. H., \& Nasiruddin, K. B. (2014). Perception of Non-Muslim consumers towards Halal products in Malaysia. International Journal of Accounting and Business Management, 2(1), 128-133.

Izberk-Bilgin, E., \& Nakata, C. C. (2016). A new look at faith-based marketing: The global halal market. Business horizons, 59(3), 285-292.

Jafari, A. (2012). Islamic marketing: insights from a critical perspective. Journal of Islamic Marketing, 3(1), 22-34.

Jafari, A., \& Süerdem, A. (2012). An analysis of material consumption culture in the Muslim world. Marketing Theory, 12(1), 61-79.

Jihan, A., Musa, R. (2014). Factors influencing attitude towards halal cosmetic among young adult Urban Muslim women: A focus group analysis. Procedia-Social and Behavioral Sciences, 130, 129-134.

Kadirov, D. (2014). Islamic marketing as macromarketing. Journal of Islamic Marketing, 5(1), 2-19.

Kadirov, D. (2020). Islamic Marketing : Theories, Practices, and Perspectives. Conscientia Capital Press.

Kamali, M. H. (2008). Shari'ah law: an introduction. Oneworld Publications.

Khan, S., \& Janmohamed, S. (2011). Meet the futurists, the new Muslim consumers. Ogilvy

Noor blog. Available online at https://halalfocus.net/opinion-meet-the-futurists-the-newmuslim-consumer/ (Last accessed June 29, 2019).

Kordnaeij, A., Askaripoor, H., \& Bakhshizadeh, A. (2013). Studying affecting factors on customers' attitude toward products with halal brand (case study: Kuala Lumpur, Malaysia). International Research Journal of Applied and Basic Sciences, 4(10), 3138-3145. 
Lokman, A. R. (2015). Pematuhan Syariah Dalam Operasi Syarikat Bagi Industri Halal. In Kompilasi Kertas Kerja Muzakarah Ahli Penasihat Syariah Institusi Kewangan di Malaysia (pp. 27 40). Putrajaya: JAKIM.

Marinova, D., Hossain, A., \& Hossain-Rhaman, P. (2008). Islam on sustainability.

International Journal of Environmental, Cultural, Economic and Social Sustainability, 4(5), 123-130.

Maxim, A. (2009). Relationship marketing-a new paradigm in marketing theory and practice. Analele Stiintifice ale Universitatii" Alexandru Ioan Cuza" din Iasi-Stiinte Economice, 56, 287-300

Muhammad, N. M. N., Isa, F. M., \& Kifli, B. C. (2009). Positioning Malaysia as halal-hub: integration role of supply chain strategy and halal assurance system. Asian Social Science, 5(7), 44-52.

Mukhtar, A., \& Mohsin Butt, M. (2012). Intention to choose Halal products: the role of religiosity. Journal of Islamic Marketing, 3(2), 108-120.

Nasir, K. M., \& Pereira, A. A. (2008). Defensive dining: Notes on the public dining experiences in Singapore. Contemporary Islam, 2(1), 61-73.

Omar, W. M. W., Muhammad, M. Z., \& Omar, A. C. (2008, December). AN ANALYSIS OF THE MUSLIM CONSUMERS'ATTITUDES TOWARDS 'HALAL'FOOD PRODUCTS IN KELANTAN. In Proceeding of the ECER Regional Conference (p. 165).

Parris, D. L., \& Peachey, J. W. (2013). A systematic literature review of servant leadership theory in organizational contexts. Journal of business ethics, 113(3), 377-393.

Pazim, K. H., Rahim, D. A., Mahmud, R., \& Lim, F. Y. B. (2010). Perceptions on halal goods and services among Muslim consumers in Kota Kinabalu, Sabah, Malaysia. In ICERI2010 Proceedings (pp. 6202-6202). IATED.

Pepinsky, T. B. (2013). Development, social change, and Islamic finance in contemporary Indonesia. World Development, 41, 157-167.

Rahim, N. F., Shafii, Z., \& Shahwan, S. (2013). Awareness and perception of muslim consumers on non-food halal product. Journal of Social and Development Sciences, 4(10), 478-487.

Rahim, N. F. B., Shafii, Z., \& Shahwan, S. (2015). Awareness and perception of muslim consumers on halal cosmetics and personal care products. International Journal of Business, Economics and Management, 2(1), 1-14.

Rahim, N. F. B. (2016). Consumer Behaviour, Perception and Planning Towards Halal Marketing. In Advances in Islamic Finance, Marketing, and Management: An Asian Perspective (pp. 271-307). Emerald Group Publishing Limited.

Ranjan, K. R., \& Read, S. (2016). Value co-creation: concept and measurement. Journal of the Academy of Marketing Science, 44(3), 290-315.

Rezai, G. (2008). Consumers' Confidence in Halal Labeled Manufactured Food in Malaysia (Doctoral dissertation, Universiti Putra Malaysia).

Saeed, M., Ahmed, Z. U., \& Mukhtar, S. M. (2001). International marketing ethics from an Islamic perspective: a value-maximization approach. Journal of Business Ethics, 32(2), $127-$ 142.

Said, M., Hassan, F., Musa, R., \& Rahman, N. A. (2014). Assessing consumers' perception, knowledge and religiosity on Malaysia's halal food products. Procedia-Social and Behavioral Sciences, 130, 120-128. 
Salman, F., \& Siddiqui, K. (2011). An exploratory study for measuring consumers awareness and perceptions towards halal food in Pakistan. Interdisciplinary Journal of Contemporary Research in Business, 3(2).

Sand1kçı, Ö. (2011). Researching Islamic marketing: past and future perspectives. Journal of Islamic Marketing, 2(3), 246-258.

Sandikci, Ö., \& Jafari, A. (2013). Islamic encounters in consumption and marketing. Marketing Theory, 13(4), $411-420$.

Shafii, Z., Shahwan, S., Muhamed, N. A., Hashim, H., Mohd, M. F., Amin, A. A. R., ... \& Zaib, S. Z. M. (2013). Product recall management for halal product. Institute for Halal Research Management (IHRAM) Universiti Sains Islam Malaysia, 3, 5.

$\mathrm{z}$

Shah, R. N., Nooh, M. N., Nawai, N., \& Muhammad, H. (2008). Is Halal product are more expensive as perceived by the consumers? Muslimpreneurs challenges and opportunities in establishing a blue ocean playing field. In 4th International Conference on Business. Bangi: UNITEN.

Shamsudin, S. M., \& Abd Rahman, S. S. (2014). The differences between Islamic marketing and conventional marketing: A review of the literature. In Proceeding of the 1st international conference on management and muamalah 2014 (1st ICoMM) (p. 298À307).

Stern, C., Jordan, Z., \& McArthur, A. (2014). Developing the review question and inclusion criteria. AJN The American Journal of Nursing, 114(4), 53-56.

Sula, M. S., \& Kartajaya, H. (2006). Syariah Marketing. Mizan Pustaka.

Temporal, P. (2011). Islamic branding and marketing: Creating a global Islamic business. John Wiley \& Sons.

The Halal Journal. (2010). Najib's take on Halal. The Halal Journal, July \& August, pp. 2429

Tournois, L., \& Aoun, I. (2012). From traditional to Islamic marketing strategies: Conceptual issues and implications for an exploratory study in Lebanon. Education, Business and Society: Contemporary Middle Eastern Issues, 5(2), 134-140.

Teng, P. K., \& Jamaliah, W. W. (2013, March). Investigating students awareness and usage intention towards halal labelled cosmetics and personal care products in Malaysia. In 4th International Conference on Business and Economic Research (4th ICBER 2013), Indonesia: Bandung.

Thorpe, R., Holt, R., Macpherson, A., \& Pittaway, L. (2005). Using knowledge within small and medium-sized firms: a systematic review of the evidence. International Journal of Management Reviews, 7(4), 257-281.

Trim, B. (2008). Business Wisdom of Muhammad SAW: 40 Kedahsyatan Bisnis Ala Nabi SAW (Business Wisdom of Muhammad SAW: 40 Business Breakthrough of Prophet SAW). Madania Prima, Bandung.

Trim, B. (2009). Brilliant Entrepreneur Muhammad SAW. Bandung: Salamadani Pustaka Semesta.

Wilson, J. A. (2012). The new wave of transformational Islamic marketing: reflections and definitions. Journal of Islamic Marketing, 3(1), 5-11.

Wilson, J. A. (2014). The halal phenomenon: an extension or a new paradigm?. Social Business, 4(3), 255-271. 
Wilson, J.A.J. (2014). Revisiting the philosophical arguments underpinning Islamic finance and Halal, [whitepaper], Zawya, pp. 1-5

Wilson, J. A., \& Grant, J. (2013). Islamic marketing-a challenger to the classical marketing canon?. Journal of Islamic Marketing, 4(1), 7-21.

Wilson, J. A., \& Liu, J. (2010). Shaping the halal into a brand?. Journal of Islamic marketing.

Wilson, J. A., \& Liu, J. (2011). The challenges of Islamic branding: navigating emotions and halal. Journal of Islamic marketing, 2(1), 28-42.

Wilson, J. A., Belk, R. W., Bamossy, G. J., Sandikci, Ö., Kartajaya, H., Sobh, R., ... \& Scott, L. (2013). Crescent marketing, Muslim geographies and brand Islam. Journal of Islamic Marketing.

Wohlin, C. (2014). Guidelines for snowballing in systematic literature studies and a replication in software engineering. In Proceedings of the 18th international conference on evaluation and assessment in software engineering (p. 38). ACM.

Zakaria, N., \& Abdul-Talib, A. N. (2010). Applying Islamic market-oriented cultural model to sensitize strategies towards global customers, competitors, and environment. Journal of Islamic Marketing, 1(1), 51-62.

Zhari, I., \& Halim, E. A. (2010). Halal nutraceutical market: issues and challenges. SEGi Review, 3(2), 96-117. 